$M P--2.2788$

\title{
CARBON DIOXIDE IN GEOTHERMAL FLUIDS
}

Harold A. Papazian

Bureau of Reclamation

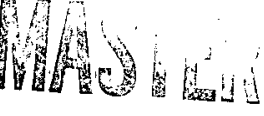

Holtville, CA 92250

\section{Abstract}

The concentration of carbon dioxide has been measured for the four production wells at the East Mesa Geothermal Test Site. The effect of flashing on the equilibria are discussed. The solubility product constant, $\mathrm{K}_{\mathrm{sp}}$, for $\mathrm{CaCO}_{3}$ is calculated at bottom hole temperatures.

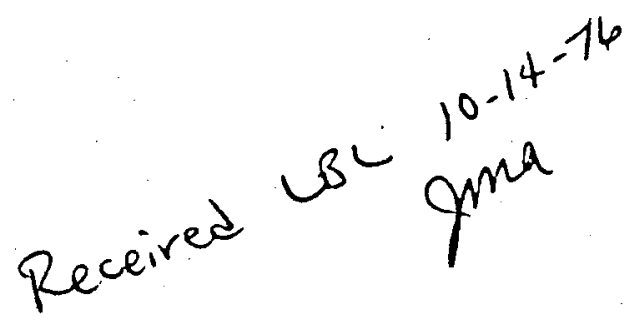




\section{DISCLAIMER}

This report was prepared as an account of work sponsored by an agency of the United States Government. Neither the United States Government nor any agency Thereof, nor any of their employees, makes any warranty, express or implied, or assumes any legal liability or responsibility for the accuracy, completeness, or usefulness of any information, apparatus, product, or process disclosed, or represents that its use would not infringe privately owned rights. Reference herein to any specific commercial product, process, or service by trade name, trademark, manufacturer, or otherwise does not necessarily constitute or imply its endorsement, recommendation, or favoring by the United States Government or any agency thereof. The views and opinions of authors expressed herein do not necessarily state or reflect those of the United States Government or any agency thereof. 


\section{DISCLAIMER}

Portions of this document may be illegible in electronic image products. Images are produced from the best available original document. 


\section{INTRODUCTION}

Carbonic acid and its ions are involved in an extraordinary number of industrial, geological, and biological processes. At a geothermal site, the concentration of $\mathrm{CO}_{2}$ in the brines is of importance both fundamentally and practicaliy. Such information can contribute to an understanding of the geology of the formation, and from a practical view it can contribute to control of carbonate scale which can be pronouced when these fluids are flashed.

The purpose of the present communication is to report: (1) the concentration of $\mathrm{CO}_{2}$ in the four production wells at the East Mesa Geothermal Site; (2) the mechanism of $\mathrm{CO}_{3}$ formation during flashing; (3) the $\mathrm{K}_{\mathrm{sp}}$ of $\mathrm{CaCO}_{3}$ at bottom hole temperatures.

The four wells at East Mesa are:

\begin{tabular}{|c|c|c|c|c|}
\hline Well & $6-1$ & $6-2$ & $8-1$ & $31-1$ \\
\hline $\begin{array}{c}\text { Bottom hole } \\
\text { Temp }{ }_{C}\end{array}$ & 200 & 190 & 180 & 160 \\
\hline TDS & 26000 & 5000 & 1600 & 2900 \\
\hline
\end{tabular}

\section{RESULTS}

Both flashed and unflashed brine was obtained at the wellhead during well flow. Mesa 6-2 had been flowing for several months; Mesa 6-1 had been 
flowing for several days at a low flow rate; Mesa 8-1 and Mesa $31-1$ were flowed through a 2" line for 24 hours. Unflashed brine was taken through a cooling coil; the temperature of the collected brine was $26^{\circ} \mathrm{C}\left(79^{\circ} \mathrm{F}\right)$ indicating efficient cooling. One sample was taken directly for $\mathrm{pH}$ and alkalinity measurements. Another sample was collected in $400 \mathrm{ml}$ of caustic, with brine introduced under the surface of the $\mathrm{NaOH}$ solution, to a total of $800 \mathrm{ml}$ of solution for $\mathrm{CO}_{2}$ concentrations. The cooling coil was then removed, $800 \mathrm{ml}$ of flashed fluid was colllected, and $400 \mathrm{ml}$ of this sample was poured into a bottle containing $400 \mathrm{~m}$ ] of caustic, followed by mixing. The hot solutions were cooled to ambient temperature, and all samples were immediately measured for $\mathrm{pH}$ and titrated for alkalinity using the standard $P$ and $M$ end points.

It is customary to represent all aqueous carbon dioxide as $\mathrm{H}_{2} \mathrm{CO}_{3}$ and to use the dissociation constants of the acid in equilibrium calculations. The equilibria of interest are:

$$
\mathrm{H}_{2} \mathrm{CO}_{3} \rightleftharpoons \mathrm{H}^{+}+\mathrm{HCO}_{3}^{-}
$$$$
k_{1}=4.31 \times 10^{-7}
$$

$$
\mathrm{HCO}_{3}^{-} \rightleftharpoons \mathrm{H}^{+}+\mathrm{CO}_{3}^{=}
$$$$
k_{2}=5.6 \times 10^{-11}
$$

$$
\mathrm{OH}^{-}+\mathrm{HCO}_{3}^{-} \rightleftharpoons \mathrm{CO}_{3}^{-}+\mathrm{H}_{2} \mathrm{O}
$$

$$
\mathrm{CO}_{2}+\mathrm{OH}^{-} \rightleftharpoons \mathrm{HCO}_{3}^{-}
$$

and the sum of (III) and (IV) leads to:

with (VI)

$$
\mathrm{CO}_{2}+2 \mathrm{OH}^{-} \rightleftharpoons \mathrm{CO}_{3}^{=}+\mathrm{H}_{2} \mathrm{O}
$$

$$
\mathrm{H}_{2} \mathrm{O} \rightleftharpoons \mathrm{H}^{+}+\mathrm{OH}^{-}
$$

The equilibrium constants are taken from the "Handbook of Physics and 
Chemistry". Collection of the brine in caustic will convert all $\mathrm{CO}_{2}$ and $\mathrm{HCO}_{3}^{-}$via equations (III) and (IV). From the alkalinity titrations one can calculate the total $\mathrm{CO}_{2}$ in solution as well as the $\mathrm{pH}$. The total recovered $\mathrm{OH}^{-}$obtained from the titration may be compared with the known concentration of the caustic used, and the calculated $\mathrm{pH}$ may be compared with the measured $\mathrm{pH}$. Both of these comparisons are a measure of the confidence level of the results obtained. The $\mathrm{pH}$ is calculated from equation (I) using the measured $\left[\mathrm{HCO}_{3}^{-}\right]$with the carbonic acid concentration

$$
\text { (VII) }\left[\mathrm{H}_{2} \mathrm{CO}_{3}\right]=\left[\mathrm{CO}_{2}\right] \text { total }-\left[\mathrm{HCO}_{3}^{-}\right]
$$

This is the value designated as "Free" $\mathrm{CO}_{2}$ in Table I where the results for unflashed brine are given.

Table I

\begin{tabular}{|c|c|c|c|c|c|}
\hline \multirow{2}{*}{ Well } & \multicolumn{2}{|c|}{$\mathrm{CO}_{2} \mathrm{ppm}$} & \multirow{2}{*}{$\mathrm{OH}^{-}$} & \multicolumn{2}{c|}{$\mathrm{pH}$} \\
\cline { 2 - 3 } & "Free" & Total & $\%$ recovery & meas. & calc. \\
\hline $6-1$ & $>1500$ & $>1700$ & 88 & 5.63 & 5.55 \\
$6-2$ & 1214 & 1544 & 99.7 & 5.75 & 5.81 \\
$31-1$ & 603 & 1090 & 101 & 6.25 & 6.27 \\
$8-1$ & 282 & 515 & 97.0 & 6.28 & 6.28 \\
\hline
\end{tabular}

Well 6-l contained so much $\mathrm{CO}_{2}$ that it was not possible to absorb all of it in caustic. That is, while no steam was observed, bubbles of gas were seen rising and escaping from the caustic solution. Increasing the depth of the collection solution some 4-5 times did not prevent the escape. Further, 
during collection of this "unflashed" brine a precipitate was formed. The precipitate was collected dried and weighed $0.1478 \mathrm{gm}$. Of this, $0.0046 \mathrm{gm}$ was insoluble in HCL. Therefore, the carbonate portion is $0.1432 \mathrm{gm}$. Assuming that $\mathrm{CaCL}_{2}$ was formed during the $\mathrm{HCl}$ treatment, the soluble material was dried and weighed $0.1630 \mathrm{gm}$. The $0.1630 / 0.1432=1.138$, in reasonably good agreement with the ratio of the molecular weights $\mathrm{CaCl}_{2} / \mathrm{CaCO}_{3}=1.11$. Therefore, it was assumed that the precipitate was $\mathrm{CaCO}_{3}$ and calculations made on that basis. The total $\mathrm{OH}^{-}$recovery was $88 \%$ indicating that not all of the precipitate was recovered. Therefore, based on this and the observation of escaping $\mathrm{CO}_{2}$, only a "greater than" value may be given for well 6-1. For these reasons no attempt was made to collect and analyze flashed $6-1$ brine as has been dorie below for the other three wells.

\section{Flashed Brines}

The flashed brines were analyzed in the same manner as the unflashed systems. The total $\mathrm{CO}_{2}$ in the flashed systems of wells $6-2,37-1$, and $8-1$ amounted to 1214,572 , and $343 \mathrm{ppm}$, respectively. We $176-2$ showed a small amount of $\mathrm{CO}_{\overline{3}}$, and the per cent caustic recovered ranged from 98.4 to 101 . Thus, it is tempting to again calculate the $\mathrm{pH}$ via equations (I) and (VII). Very poor agreement is obtained. If the measured $\mathrm{pH}$ is used and the $\left[\mathrm{H}_{2} \mathrm{CO}_{3}\right]$ is calculated, the carbonic acid concentrations for the three flashed systems are all near $8 \times 10^{-5} \mathrm{M}$, much smalier than that when equation (VII) is used. This will be commented on below.

The flashed systems reach a pH near 8.3, and any mechanism for flashing must account for the increase of $\mathrm{pH}$ and carbonate ion production concomitant with the loss of carbon dioxide during the process. The sudden release of $\mathrm{CO}_{2}$ (and therefore reduction in $\mathrm{H}_{2} \mathrm{CO}_{3}$ ) momentarily leaves the system with a 
disproportionately high concentration of $\mathrm{HCO}_{3}^{-}$than required by equation (I). The bicarbonate ion then undergoes hydrolysis and disproportionation reactions

$$
\begin{aligned}
& \text { (VIII) } \mathrm{HCO}_{3}^{-}+\mathrm{H}_{2} \mathrm{O} \rightleftharpoons \mathrm{H}_{2} \mathrm{CO}_{3}+\mathrm{OH}^{-} \\
& \text {(IX) } \quad 2 \mathrm{HCO}_{3}^{-} \rightleftharpoons \mathrm{H}_{2} \mathrm{CO}_{3}+\mathrm{CO}_{3}^{-} .
\end{aligned}
$$

Consideration of these two reactions leads to

$$
\text { (x) } \quad\left[\mathrm{H}_{2} \mathrm{CO}_{3}\right]=\left[\mathrm{OH}^{-}\right]+\left[\mathrm{CO}_{3}^{-}\right] \text {. }
$$

Using the appropriate equilibria $K_{1}, K_{2}$, and $K_{w}$ yields

$$
\begin{gathered}
\frac{\left[\mathrm{H}^{+}\right]\left[\mathrm{HCO}_{3}^{-}\right]}{\mathrm{K}_{1}}=\frac{\mathrm{K}_{\mathrm{W}}}{\left[\mathrm{H}^{+}\right]}+\frac{\mathrm{K}_{2}\left[\mathrm{HCO}_{3}^{-}\right]}{\left[\mathrm{H}^{+}\right]} \\
{\left[\mathrm{H}^{+}\right]^{2}=\frac{\mathrm{K}_{1} \mathrm{~K}_{\mathrm{W}}}{\left[\mathrm{HCO}_{3}^{-}\right]}+\mathrm{K}_{1} \mathrm{~K}_{2}} \\
\text { (XI) }\left[\mathrm{H}^{+}\right]^{2}=\frac{4.45 \times 10^{-21}}{\left[\mathrm{HCO}_{3}^{-}\right]}+2.1 \times 10^{-17}
\end{gathered}
$$

Table II lists the $\mathrm{pH}$ values calculated along with the measured bicarbonate concentrations and $\mathrm{pH}$.

Table II

\begin{tabular}{|l|l|l|l|}
\hline \multirow{2}{*}{ Well } & \multirow{2}{*}{$\begin{array}{l}\mathrm{HCO}_{3}^{-} \\
\text {meas. }\end{array}$} & \multicolumn{2}{|c|}{$\mathrm{pH}$} \\
\cline { 2 - 4 } & meas. & Eqn (XI) \\
\hline $6-2$ & $8.54 \times 10^{-3} \mathrm{M}$ & 8.35 & 8.31 \\
$31-1$ & $5.8 \times 10^{-3}$ & 8.27 & 8.30 \\
$8-1$ & $1.15 \times 10^{-2}$ & 8.48 & 8.31 \\
\hline
\end{tabular}


Using the development for equation (XI) the carbonic acid concentrations are calculated to be in the range $6-13 \times 10^{-5} \mathrm{M}$, in good agreement with the vatues near $8 \times 10^{-5} M$ discussed above. This is a further indication for the correcteness of the suggested mechanism for flashing.

The Solubility Product, $\mathrm{Ksp}$, for $\mathrm{CaCO}_{3}$

In the following discussion activities are not considered - the salinities of these wells are relatively low. The solubility product is reported by Homer (1) for temperatures up to $80^{\circ} \mathrm{C}$. Using seawater data, Standiford (2) has extended these to $125^{\circ} \mathrm{C}$. In Figure 1 these are the solid line and broken line, respectiveiy. The dashed line is a further extrapolation for the following discussion.

In the geothermal aquifer, the equilibria of the solubility product

$$
k_{s p}=\left[\mathrm{Ca}^{++}\right]\left[\dot{\mathrm{CO}}_{3}^{\overline{3}}\right]
$$

and equation (II) coexist.

$$
\mathrm{K}_{2}=\frac{\left[\mathrm{H}^{+}\right]\left[\mathrm{CO}_{3}^{-}\right]}{\left[\mathrm{HCO}_{3}^{-}\right]}
$$

A simple manipulation yields

$$
\left[\mathrm{Ca}^{++}\right]=\frac{\mathrm{K}_{\mathrm{sp}}}{\mathrm{K}_{2}} \cdot \frac{\left.\mathrm{H}^{+}\right]}{\left[\mathrm{HCO}_{3}^{-}\right]}
$$

The ionization constant $K_{2}$ is a function of temperature and has been given by Homer (1) for temperature up to $80^{\circ} \mathrm{C}$. These have been extended by Standiford (2) to $125^{\circ} \mathrm{C}$ using data for seawater. A further extrapolation of these data indicate a variation from $5.3 \times 10^{-11}$ for the hotest well at East Mesa to a value of $6.2 \times 10^{-11}$ for the coldest we11. Therefore, the ambient value of 
$5.6 \times 10^{-11}$ will be used to calculate the $\mathrm{Ca}^{++}$concentrations in each well using the dashed line extrapolation in Figure $\mathrm{l}^{5}$ for $\mathrm{KSp}_{\mathrm{Sp}}$ and $\left[\mathrm{H}^{+}\right]$and $\left[\mathrm{HCO}_{3}^{-}\right]$ as measured in the unflashed brines. Table III compares these calculations with the measured values of $\left[\mathrm{Ca}^{++}\right]$. It also lists the $\mathrm{K}_{\mathrm{sp}}$ calculated using the measured concentrations of $\mathrm{Ca}^{++}, \mathrm{H}^{+}$, and $\mathrm{HCO}_{3}^{-}$.

Table III

\begin{tabular}{|c|c|c|c|c|c|}
\hline \multirow{2}{*}{ Well } & \multirow{2}{*}{$\begin{array}{l}\text { Temp } \\
{ }^{\circ} \mathrm{C}\end{array}$} & \multicolumn{2}{|c|}{$\mathrm{Ca}^{++}$} & \multirow{2}{*}{$\begin{array}{c}\text { Ratio } \\
\left(\frac{\text { meas. }}{\text { calc. }}\right)\end{array}$} & \multirow{2}{*}{$\begin{array}{l}\mathrm{K}_{\mathrm{sp}} \\
\mathrm{calc} .\end{array}$} \\
\hline & & meas. & calc. & & \\
\hline $6-1$ & 200 & $3.4 \times 10^{-2} \mathrm{M}$ & $3.8 \times 10^{-4} \mathrm{M}$ & 90 & 8.75 \\
\hline $6-2$ & 190 & $4.1 \times 10^{-4}$ & $4.4 \times 10^{-5}$ & 9 & 9.65 \\
\hline $8-7$ & 179 & $2.12 \times 10^{-4}$ & $5.6 \times 10^{-5}$ & 4 & 9.82 \\
\hline $37-1$ & 163 & $2.32 \times 10^{-4}$ & $4.1 \times 10^{-5}$ & 6 & 9.48 \\
\hline
\end{tabular}

Since the calculated values of $\mathrm{Ca}^{++}$are in remarkably good agreement with the measured values using the extrapolated values of $K_{S p}$, the calculated $K_{s p}$ may be meaningful and indicate a either reversal in the temperature effect on solubility near $180^{\circ} \mathrm{C}$ or sources of $\mathrm{Ca}^{++}$other than considered. It may be noted that the discrepancies follow the TDS values of the wells, therefore in all probability the $K_{s p}$ are close to the extrapolated values.

\section{References}

(1) Homer, "Industrial Water Treatment Practice", Buttersworth, London 1961.

(2) Standiford, F. C., "The Carbonate - Bicarbonate - Carbon Dioxide System in Seawater", Distillation Digest, $\underline{6}, 17(1972)$. 
